\title{
Analisis Proses Pembelajaran Matematika pada Masa COVID-19
}

\author{
Salbiyah Simbolon ${ }^{1}$, Amin Harahap ${ }^{2}$ \\ ${ }^{1,2}$ Program Studi Pendidikan Matematika, Fakultas Ilmu Pendidikan, Universitas Labuhanbatu, \\ Jl.Sisingamangaraja, Labuhanbatu, Sumatera Utara (21415) Indonesia \\ salbiyahsimbolon09@gmail.com
}

\begin{abstract}
The purpose of this research is to analyze the process of learning mathematics during the COVID-19 pandemic for elementary school students. The research method used is descriptive qualitative, to provide an overview of learning during the COVID-19 pandemic in schools. Techniques for collecting data are questionnaires, observations and interviews. The population in this study were 98 students and 4 teachers. The indicators of the questionnaire distributed are in the form of evaluating students' ability to understand and implement mathematics during the COVID-19 pandemic. Based on the results of the questionnaire that researchers have obtained, it is known that $37 \%$ of students choose to answer the statement with hesitation, $6 \%$ of students feel strongly disagree with all the statements that the researcher gives, then $15 \%$ feel disagree, and $28 \%$ for the statement agree and $14 \%$ strongly agree, so it is concluded that the process of learning mathematics during the covid-19 pandemic has many obstacles even though the government has given instructions for online learning. These obstacles occur because there are differences between students who live in cities and students who live in the regions, the obstacles such as the problem of students who do not have gadgets so they cannot take online classes, there are economic constraints that affect the purchase of data packages, and there are obstacles in unstable internet network.
\end{abstract}

Keywords: Mathematics, Covid-19, Learning Process

\begin{abstract}
Abstrak
Tujuan dari riset ini adalah untuk menganalisis proses pembelajaran matematika pada masa pandemi covid-19 terhadap siswa sekolah dasar. Metode penelitian yang digunakan adalah kualitatif deskriptif, untuk memberikan gambaran pembelajaran pada masa pandemik covid-19 di sekolah. Teknik untuk mengumpulkan data dengan metode angket, observasi dan wawancara. Populasi dalam penelitian ini adalah sebanyak 98 siswa dan 4 guru. Adapun indikator dari angket yang disebarkan berupada evaluasi kemampuan pemahaman dan implementasi matematika siswa pada masa pandemi covid-19. Berdasarkan hasil dari angket yang telah peneliti peroleh diketahui $37 \%$ siswa memilih untuk menjawab pernyataan dengan ragu-ragu, $6 \%$ siswa merasa sangat tidak setuju untuk semua pernyataan yang peneliti berikan, kemudian 15\% merasa tidak setuju, serta sebesar 28\% untuk keterangan setuju dan 14\% sangat setuju, sehingga disimpulkan bahwa proses pembelajaran matematika pada masa pandemi covid-19 terdapat banyak kendala meskipun pemerintah telah memberikan instruksi untuk dilakukannya pembelajaran secara daring. Adapun kendala tersebut terjadi karena terdapat perbedaan antara siswa yang tinggal di kota dengan siswa yang tinggal di daerah, kendalanya seperti masalah adanya siswa yang tidak memiliki gadget sehingga tidak dapat mengikuti kelas daring, adanya kendalah dalam ekonomi yang mempengaruhi pembelian paket data, dan adanya kendala dalam jaringan internet yang tidak stabil.
\end{abstract}

Kata kunci: Matematika, Covid-19, Proses Belajar

Copyright (c) 2021 Salbiyah Simbolon, Amin Harahap

$\square$ Corresponding author: Salbiyah Simbolon

Email Address: salbiyahsimbolon09@gmail.com (Jl. Sisingamangaraja, Labuhanbatu, SUMUT (21415) Indonesia)

Received 07 June 2021, Accepted 29 June 2021, Published 21 July 2021

\section{PENDAHULUAN}

Sejak Desember 2019 negara mengalami pandemi secara global, yakni mewabahnya virus baru yang disebut Coronavirus Deseae. Covid-19 merupakan penyakit jenis baru yang belum pernah diidentifikasi sebelumnya pada manusia. Pada 2 maret 2020, terdapat dua kasus pertama kali dikonfirmasi di Indonesia, selanjutnya menjadi 790 kasus pada minggu ketiga (Wulandari et al., 2020). Pemerintah melalui kementerian kesehatan menerbitkan peraturan menteri kesehatan No.9 Tahun 2020 tentang Pedoman Pembatasan Sosial Berskala Besar (PSBB)(Hairi, 2020), yang mana pembatasan tersebut meliputi 
meliburkan sekolah-sekolah, kampus-kampus, tempat kerja, kegiatan keagamaan, pembatasan ditempat/fasilitas umum, pembatasan sosial budaya, dan pembatasan lainnya yang menimbulkan keramaian guna untuk memutus rantai penularan covid-19 (Irfanudin et al., 2020).

Sejak PSBB diberlakukan, pemerintah menginstruksikan kebijakan baru yaitu melakukan kegiatan belajar mengajar di rumah secara daring. Hal ini dilakukan agar siswa tidak berhenti mendapatkan pendidikan sekaligus untuk membantu pemerintah dalam memutus mata rantai penularan covid-19 di Indonesia. Menurut Skiner dalam (Ratnawati, 2016) menyatakan bahwa pendidikan merupakan segala usaha yang dirancang untuk mempengaruhi manusia yang awal mulanya tidak tahu menjadi memiliki pengetahuan melalui pembelajaran sehingga dapat merubah pola pikirnya. Tujuan pendidikan adalah indikator keberhasilan pelaksanaan pendidikan.

Pembelajaran daring ialah sebuah pembelajaran yang dilakukan secara jarak jauh berbantuan media internet dan perangkat bantu lainnya seperti telepon seluler, laptop dan komputer (Patimah, 2020).Artinya, bahwa pelaksanaan pembelajaran daring memakai unsur teknologi sebagai sarana dan internet sebagai sistem (Fitriyani et al., 2020). Setyorini dalam (Handayani, 2020) menjelaskan keuntungan dari pembelajaran daring adalah waktu tidak terbatas, masih banyak waktu luang dan menghemat biaya transportasi. Akan tetapi dalam praktinya, pembelajaran daring tidak semaksimal pembelajaran dikelas, terutama pada pelajaran matematika.

Pendidikan matematika merupakan salah satu ilmu pengetahuan yang memiliki peranan penting dalam perkembangan Ilmu Pengetahuan dan Teknologi (IPTEK) sehingga menjadi aspek yang sangat penting untuk meningkatkan kualitas Sumber daya manusia. Matematika berperan besar dalam mempersiapkan Sumber Daya Manusia (SDM) agar mampu menghadapi tantangan era globalisasi

Matematika ialah salah satu bidang ilmu pengetahuan eksak yang lebih mementingkan pemahaman siswa dari pada hapalan. Tujuan pembelajaran matematika yang ditetapkan oleh Dapartemen Pendidikan Nasional (2006)(Taunu \& Iriani, 2019) sejalan dengan pernyataan NCTM bahwa terdapat lima kompetensi dalam pembelajaran matematika yaitu pemecahan masalah matematis (Mathematical Problem Solving), komunikasi matematis (Mathematical Communication), penalaran matematis (Mathematical Reasoning), koneksi matematis (Mathematical Connection), dan representasi matematis (Mathematical Connection)(Wibowo, 2019). Gabungan kelima kompetensi tersebut perlu dimiliki siswa agar dapat mempergunakan ilmu matematika dalam kehidupan sehari-hari. Kemampuan yang mencakup kelima kompetensi tersebut adalah kemampuan literasi matematika (Saleh et al., 2014).

Belajar adalah suatu aktivitas atau suatu proses untuk memperoleh pengetahuan, meningkatkan keterampilan, memperbaiki perilaku, sikap dan mengokohkan kepribadian (Hanafy, 2014). Menurut (Azhar Arsyad, 2013). Pembelajaran adalah segala sesuatu yang dapat membawa informasi dan pengetahuan dalam interaksi yang berlangsung antara pendidik dengan peserta didik. Proses pembelajaran merupakan proses yang di dalamnya terdapat kegiatan interaksi antara guru dan peserta didik serta komunikasi timbal balik yang berlangsung dalam situasi edukatif untuk mencapai tujuan belajar (Nugraha, 2018).

Berdasarkan yang telah dipaparkan diatas penelitian ini bertujuan untuk menganalisis proses 
pembelajaran matematika pada masa pandemik covid-19, dimana pada masa covid-19 banyak terdapat perubahan yang signifikan terhadap proses belajar terhadap siswa, dimana kendala yang terjadi bukan hanya pada kemampuan pemahaman siswa melainkan ada kendala dalam intrumen yang digunakan dalam proses belajar seperti gadget, jaringan, kuota internet dan faktor ekonomi yang menyebabkan adanya perbedaan dalam menerima pembelajaran oleh siswa di sekolah.

\section{METODE}

Metode penelitian yang digunakan adalah kualitatif deskriptif, untuk memberikan gambaran pembelajaran pada masa pandemik covid-19 di sekolah. Penelitian kualitatif merupakan metode penelitian naturalistic dikarenakan penelitiannya dilaksanakan pada kondisi yang apa adanya (natural setting) (Darmalaksana, 2020). Teknik untuk mengumpulkan data dengan metode Observasi, angket dan wawancara.Observasi dalam penelitian ini tidak melibatkan peneliti secara langsung dan obervasi dilakukan untuk mengetahui proses belajar di SDIT Al-Azhar dan SDIT Imam Syafi'i, kemudian melakukan penyebaran angket secara langsung kepada siswa, angket tersebut disebarkan secara acak kepada responden, serta melakukan wawancara terhadap guru untuk mengetahui proses pembelajaran matematika terhadap siswa pada masa pandemi covid-19. Subjek penelitian ialah siswa dan guru SDIT Al-Azhar dan SDIT Imam Syafi'i. Populasi dalam penelitian ini adalah sebanyak 98 siswa dan 4 guru. Adapun angket yang disebarkan berupa evaluasi pribadi siswa terhadao kemampuannya dalam pemahaman dan implementasi matematika selama proses pembelajaran pada masa pandemi covid-19. Berikut adalah roadmap penelitian yang penulis lakukan:

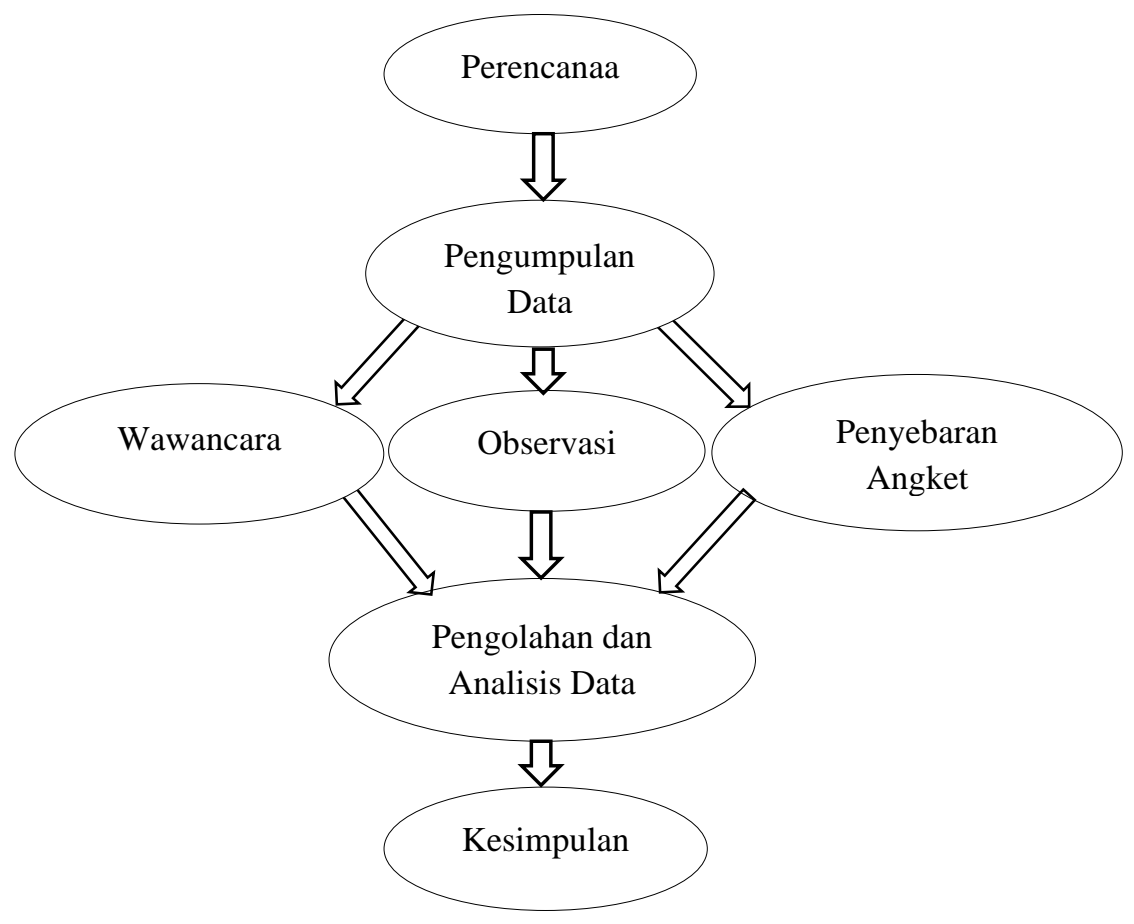

Gambar 1. Roadmap Penelitian 


\section{HASIL DAN DISKUSI}

Hasil penelitian dari analisis proses pembelajaran matematika pada masa pandemi covid-19 dianalisis dengan melihat hasil dari hasil observasi, angket yang telah disebarkan kepada siswa dan hasil dari wawancara terhadap guru matematika. Berikut masing-masing hasil yang telah peneliti peroleh.

\section{Observasi}

Proses belajar yang dilakukan pada SDIT Al-Azhar dan SDIT Imam Syafi'i adalah belajar secara daring dimana materi pembelajaran matematika diberikan melalui aplikasi pesan Whatsapp dan pengumpulan tugas matematika menggunakan google classroom dan juga secara langsung diantar ke sekolah. Serta untuk ujian diberikan soal tertulis yang diambil langsung ke sekolah dan dikumpulkan beberapa hari setelahnya sehingga untuk hasil tes tidak dapat dipastikan keabsahaannya karena dikerjakan dirumah tanpa pengawasan dari guru

\section{Angket}

Angket atau kuisioner diberikan kepada siswa SDIT Al-Azhar dan SDIT Imam Syafi'i, angket yang peneliti berikan kepada siswa terdiri dari 15 butir pernyataan dimana pernyataan tersebut bertujuan untuk melihat dan mengetahui kemampuan siswa pada pelajaran matematika selama masa pandemi covid-19 dan diberlakukannya pembelajaran dari rumah atau daring berdasarkan tanggapan dan pemahaman pribadi siswa (bukan melalui nilai hasil tes/ ujian). Angket tersebut berupa angket dengan skala likert dimana setiap pernyataan terdapat 5 pilihan yaitu sangat setuju, setuju, ragu-ragu, tidak setuju, dan sangant tidak setuju. Berikut angket yang diberikan kepada siswa:

Tabel 1. Angket

\begin{tabular}{|c|c|c|c|c|c|c|}
\hline \multirow{2}{*}{ No } & \multirow{2}{*}{ Pernyataan } & \multicolumn{5}{|c|}{ Keterangan } \\
\hline & & STS & TS & RG & $\mathbf{S}$ & SS \\
\hline 1 & $\begin{array}{l}\text { Saya memahami masalah matematika yang ada pada soal dengan } \\
\text { baik }\end{array}$ & & & & & \\
\hline 2 & $\begin{array}{l}\text { Setelah memahami masalah dalam soal, saya mencoba merumuskan } \\
\text { masalah }\end{array}$ & & & & & \\
\hline 3 & $\begin{array}{l}\text { Saya mengubah permasalahan nyata menjadi model matematika } \\
\text { sebelum mengerjakannya }\end{array}$ & & & & & \\
\hline 4 & $\begin{array}{l}\text { Saya mengecek kembali pada model matematika yang saya gunakan } \\
\text { untuk menyelesaikan soal }\end{array}$ & & & & & \\
\hline 5 & $\begin{array}{l}\text { Saya dapat menyajikan hasil dalam bentuk tabel, diagram, } \\
\text { persamaan ataupun rumus }\end{array}$ & & & & & \\
\hline 6 & $\begin{array}{l}\text { Saya dapat menggunakan tabel, diagram, rumus secara benar dan } \\
\text { tepat sesuai dengan situasi matematika }\end{array}$ & & & & & \\
\hline 7 & $\begin{array}{l}\text { Saya menggunakan fakta yang terdapat dalam permasalahan nyata } \\
\text { untuk menemukan solusi }\end{array}$ & & & & & \\
\hline 8 & $\begin{array}{l}\text { Saya mengetahui kesesuain dari solusi yang saya dapat terhadap } \\
\text { pemecahan permasalahan nyata }\end{array}$ & & & & & \\
\hline 9 & $\begin{array}{l}\text { Saya menghubungkan permasalahan nyata dalam soal dengan simbol } \\
\text { - simbol agar berubah menjadi bentuk matematika }\end{array}$ & & & & & \\
\hline 10 & $\begin{array}{l}\text { Dalam menyelesaikan soal, saya menggunakan alat-alat matematika } \\
\text { seperti penggrais, jangka,busur, dan lain-lain dengan baik dan benar }\end{array}$ & & & & & \\
\hline 11 & Saya bisa menjelaskan kepada teman apa yang guru ajarkan & & & & & \\
\hline
\end{tabular}




\begin{tabular}{|c|l|l|l|l|l|}
\hline 12 & $\begin{array}{l}\text { Saya dapat menggunakan pengetahuan matematika saya untuk } \\
\text { memecahkan masalah sehari - hari }\end{array}$ & & & \\
\hline 13 & Saya dapat menghubungkan materi satu sama lain sesuai kebutuhan & & & & \\
\hline 14 & Saya selalu aktif menjawab pertanyaan yang diajukan oleh guru & & & & \\
\hline 15 & $\begin{array}{l}\text { Keterampilan matematika saya meningkat setelah mengikuti } \\
\text { pelajaran matematika. }\end{array}$ & & & \\
\hline
\end{tabular}

Berikut hasil dari angket yang telah peneliti rangkum dalam bentuk tabel dan diagram:

Tabel 2. Hasil Angket

\begin{tabular}{|l|l|l|l|}
\hline No & Keterangan & Jumlah Nilai & $\%$ \\
\hline 1 & Sangat Tidak Setuju & 95 & $6 \%$ \\
\hline 2 & Tidak Setuju & 216 & $15 \%$ \\
\hline 3 & Ragu-Ragu & 545 & $37 \%$ \\
\hline 4 & Setuju & 411 & $28 \%$ \\
\hline 5 & Sangat Setuju & 203 & $14 \%$ \\
\hline
\end{tabular}

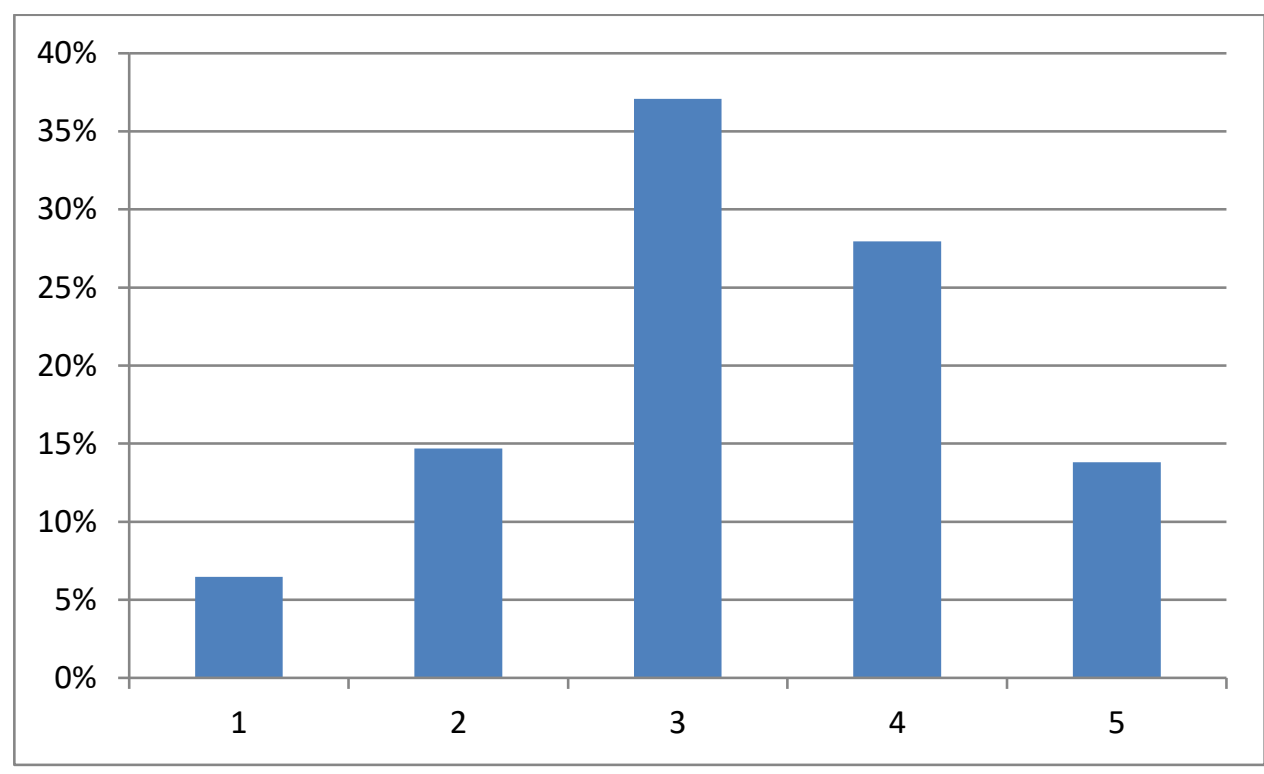

Gambar 2. Diagram hasil Angket

Berdasarkan hasil dari angket yang telah peneliti peroleh diketahui $37 \%$ siswa memilih untuk menjawab pernyataan dengan ragu-ragu akan kemampuan belajar mereka selama masa pandemi covid-19, $6 \%$ siswa merasa sangat tidak setuju untuk semua pernyataan yang peneliti berikan, dan kemudian sebanyak 15\% merasa tidak setuju, untuk hasil keterangan setuju dan sangat setuju masing-masing peneliti peroleh sebesar $28 \%$ untuk keterangan setuju dan 14\% sangat setuju. Sehingga dapat dikatakan bahwa dalam masa pandemi covid-19 siswa banyak mengalami kendala dalam belajar sehingga siswa merasa ragu akan kemampuan belajarnya khusunya dalam pelajaran matematika

\section{Wawancara}

Wawancara yang peneliti lakukan adalah wawancara tersruktur dimana pertanyaan terdiri dari 3 pertanyaan wajib dan 2 pertanyaan opsional. Wawancara tersebut peneliti lakukan terhadap guru yang 
bertugas mengajar matematika pada SDIT Al-Azhar dan SDIT Imam Syafi'i. Adapun hasil wawancara adalah sebagai berikut:

Tabel 3. Hasil Wawancara

\begin{tabular}{|c|c|c|}
\hline Nama & Pertanyaan & Jawaban \\
\hline \multirow[t]{5}{*}{$\begin{array}{l}\text { Rita Zahara } \\
\text { Siregar, S.Pd. }\end{array}$} & $\begin{array}{l}\text { Bagaimana proses belajar } \\
\text { siswa pada masa pandemi } \\
\text { covid-19? }\end{array}$ & $\begin{array}{l}\text { Proses belajar pada masa pandemi ini sangat tidak } \\
\text { kondusif dikarenakan guru tidak bertatap muka } \\
\text { secara langsung kepada seluruh siswa }\end{array}$ \\
\hline & $\begin{array}{l}\text { Apa kendala yang dihadapi } \\
\text { oleh guru pada masa } \\
\text { pandmi covid-19? }\end{array}$ & $\begin{array}{l}\text { a. Semangat anak-anak dalam proses belajar } \\
\text { berkurang } \\
\text { b. Tidak semua anak-anak memiliki handphone } \\
\text { atau paket data yang digurnakan untuk } \\
\text { melaksanakan pembelajarang daring }\end{array}$ \\
\hline & $\begin{array}{l}\text { Bagaimana hasil belajar } \\
\text { siswa pada masa pandemi } \\
\text { covid-19? }\end{array}$ & Menurun sekali \\
\hline & $\begin{array}{l}\text { Adakah solusi yang dapat } \\
\text { diberikan oleh guru untuk } \\
\text { meningkatkan proses } \\
\text { belajar siswa khususnya } \\
\text { pada masa pandemi covid- } \\
19 ? \\
\end{array}$ & $\begin{array}{l}\text { Solusinya adalah melaksanakan pembelajaran } \\
\text { secara tatap muka dengan mematuhi protokol } \\
\text { kesehatan }\end{array}$ \\
\hline & $\begin{array}{c}\text { Apa harapan guru } \\
\text { kedepannya dalam masa } \\
\text { pandemi covid-19 terkait } \\
\text { dengan poses belajar siswa? }\end{array}$ & $\begin{array}{l}\text { Kedepannya semoga pandemi cepat berlalu, } \\
\text { sehingga bisa belajar kembali seperti biasa }\end{array}$ \\
\hline \multirow[t]{5}{*}{ Risma Mulyani } & $\begin{array}{l}\text { Bagaimana proses belajar } \\
\text { siswa pada masa pandemi } \\
\text { covid-19? }\end{array}$ & $\begin{array}{l}\text { Untuk proses pembelajaran terkendala, karena } \\
\text { untuk pembelajaran MTK jika hanya di jelaskan } \\
\text { menggunakan media seperti video, anak - anak } \\
\text { belum tentu paham. }\end{array}$ \\
\hline & $\begin{array}{l}\text { Apa kendala yang dihadapi } \\
\text { oleh guru pada masa } \\
\text { pandmi covid-19? }\end{array}$ & $\begin{array}{l}\text { Kendalanya banyak, salah satunya guru atau orang } \\
\text { tua murid harus mempunyai hp yang bisa } \\
\text { terhubung ke whatsapp, kemudian harus } \\
\text { mempunyai paket, jaringan yang hilang timbul }\end{array}$ \\
\hline & $\begin{array}{l}\text { Bagaimana hasil belajar } \\
\text { siswa pada masa pandemi } \\
\text { covid-19? }\end{array}$ & Tidak stabil karena dalam masa pandemi \\
\hline & $\begin{array}{c}\text { Adakah solusi yang dapat } \\
\text { diberikan oleh guru untuk } \\
\text { meningkatkan proses } \\
\text { belajar siswa khususnya } \\
\text { pada masa pandemi covid- } \\
19 ? \\
\end{array}$ & Solusinya berharap bisa sekolah seperti biasa \\
\hline & $\begin{array}{c}\text { Apa harapan guru } \\
\text { kedepannya dalam masa } \\
\text { pandemi covid-19 terkait } \\
\text { dengan poses belajar siswa? }\end{array}$ & $\begin{array}{l}\text { Covid-19 cepat selesai atau pemerintah bisa } \\
\text { setidaknya memberikan fasilitas kepada siswa } \\
\text { yang kurang mampu sehingga dapat belajar secara } \\
\text { daring }\end{array}$ \\
\hline $\begin{array}{l}\text { Desi M. Rambe, } \\
\text { S.Pd. }\end{array}$ & $\begin{array}{l}\text { Bagaimana proses belajar } \\
\text { siswa pada masa pandemi } \\
\text { covid-19? }\end{array}$ & $\begin{array}{l}\text { Proses pembelajaran pada masa covid-19 yaitu } \\
\text { mengikuti arahan dari pemerintah dengan } \\
\text { melakukan pembelajaran daring dari rumah } \\
\text { masing-masing. }\end{array}$ \\
\hline
\end{tabular}




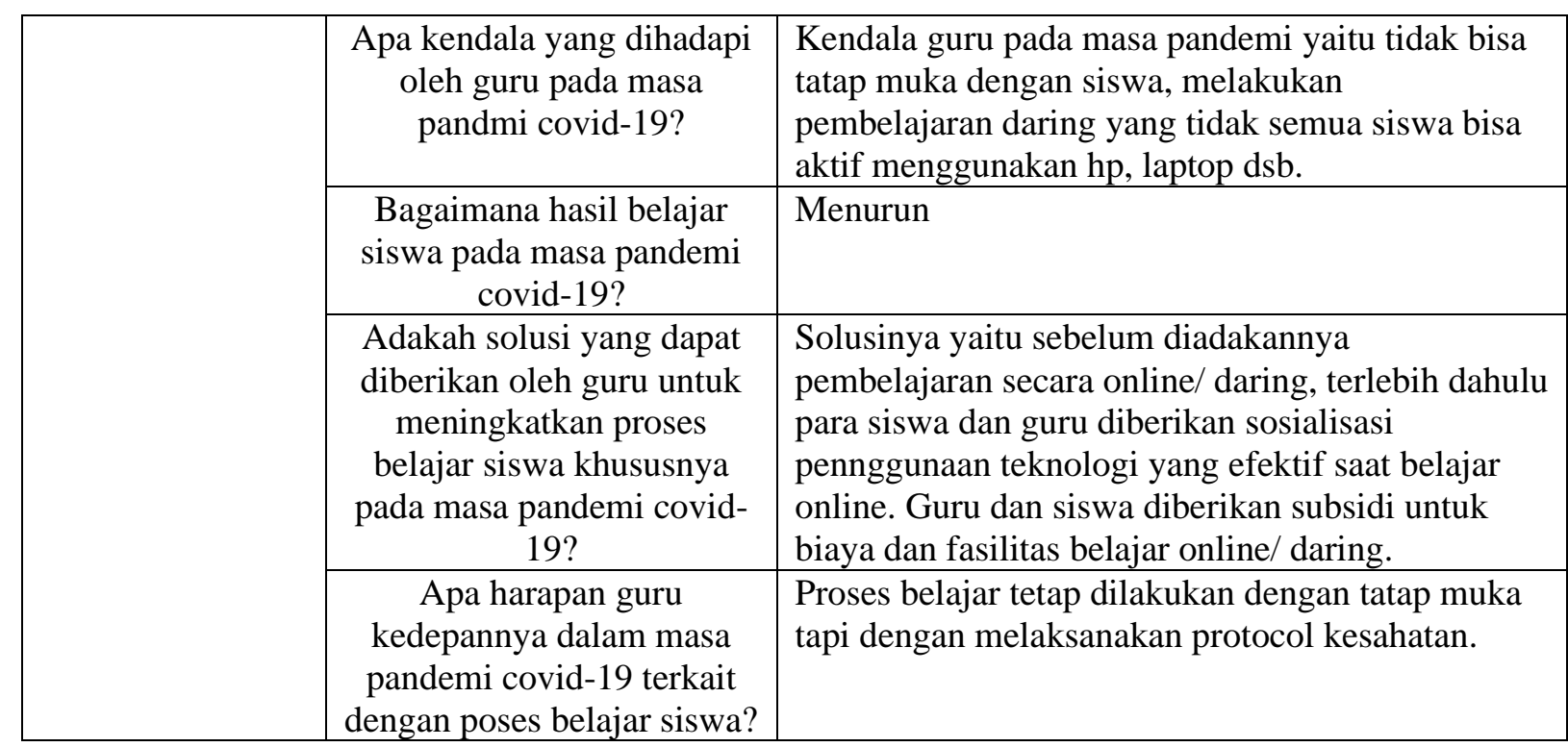

Berdasarkan hasil wawancara yang peneliti peroleh terdapat banyak kendala dalam proses belajar siswa pada masa pandemi covid-19, khususnya pada pelajaran matematika. Responden berpendapat bahwa proses belajar sangat tidak kondusif karena harus belajar dari rumah, semangat siswa dalam belajar juga menurun yang mengakibatkan hasil belajar menurun. Meskipun telah diberlakukan pembelajaran daring tetap terjadi penurunan belajar siswa karena tidak semua siswa dapat melakukan pembelajaran daring yang disebabkan karena tidak memiliki gadget yang memadai untuk pembelajaran dari serta paket internet yang berbayar dan jaringa yang tidak stabil untuk daerah diluar kota. Responden juga mengatakan untuk pembelajaran daring seharungnya pemerintah melakukan sosialisasi atau pelatihan terlebih dahulu baik itu terhadap siswa maupun tenaga pengajar sehingga pembelajaran daring dapat dilakukan dengan baik dan siswa dapat mengikutinya. Selain itu responden juga berharap adanya pembelajaran secara tatap muka dengan mengikuti protocol kesahatan sebab pelajaran matematika sangat susah untuk dijelaskan hanya melalui pesan, video ataupun suara dan juga siswa tidak bisa langsun bertanya untuk hal-hal yang mereka kurang paham yang disebabkan waktu dan tempat yang terbatas ketika melakukan pembelajaran secara daring.

\section{KESIMPULAN}

Berdasarkan dari hasil analisis yang telah peneliti lakukan baik itu melalui hasil angket yang diberikan kepada siswa maupun wawancara langsung terhadap guru matematika, maka penulis mengambil kesimpulan bahwa proses pembelajaran matematika pada masa pandemi covid-19 terdapat banyak kendala meskipun pemerintah telah memberikan instruksi untuk dilakukannya pembelajaran secara daring. Adapun kendala tersebut terjadi karena terdapat perbedaan antara siswa yang tinggal di kota dengan siswa yang tinggal di daerah, kendalanya seperti masalah adanya siswa yang tidak memiliki gadget sehingga tidak dapat mengikuti kelas daring, adanya kendalah dalam ekonomi yang mempengaruhi pembelian paket data, dan adanya kendala dalam jaringan internet yang tidak stabil. Oleh sebab itu sebanyak $37 \%$ siswa memilih ragu- 
ragu dalam hal kemampuan merekan terhadap pelajaran matematika dan bahakan terdapat $6 \%$ siswa merasa sangant tidak bisa dalam pelajaran matematika selama pandemi covid-19. Berdasarkan hal tersebut diharapkan adanya pembaharuan untuk proses belajar siswa khusunya matematika yang memungkinkan siswa untuk belajar secara tatap muka dengan tetap mematuhi protokol kesehatan pada masa pandemi covid19.

Penelitian ini sejalan dengan penelitian yang dilakukan oleh Faisal dalam Proses Pembelajaran Matematika pada masa Covid-19 di MAN 2 Langkat, dimana selama adanya pembatasan sosial masyarat dan juga terhadap proses pembelajaran, diketahui proses pembelajaran pada sekolah dilakukan dengan cara daring, baik itu untuk pemberian materi maupun pemberian tes.

\section{REFERENSI}

Azhar Arsyad. (2013). Azhar Arsyad, Media Pembelajaran , PT. Raja Grafindo Persada, Jakarta, 2013, hlm. 3. 7-39.

Darmalaksana, W. (2020). Metode Penelitian Kualitatif Studi Pustaka dan Studi Lapangan. Pre-Print Digital Library UIN Sunan Gunung Djati Bandung, 1-6. http://digilib.uinsgd.ac.id/32855/1/Metode Penelitian Kualitatif.pdf

Fitriyani, Y., Fauzi, I., \& Sari, M. Z. (2020). Motivasi Belajar Mahasiswa Pada Pembelajaran Daring Selama Pandemik Covid-19. Profesi Pendidikan Dasar, 7(1), 121-132. https://doi.org/10.23917/ppd.v7i1.10973

Hairi, P. J. (2020). Implikasi Hukum Pembatasan Sosial Berskala Besar Terkait Pencegahan COVID-19. Info Singkat Bidang Hukum, 12(April), 1-6. http://berkas.dpr.go.id/puslit/files/info_singkat/Info Singkat-XII-7-I-P3DI-April-2020-\%0A240.pdf\%0A

Hanafy, M. S. (2014). Konsep dan Pembelajaran. Lentera Pendidikan, 17(1), 66-79. http://103.55.216.55/index.php/lentera_pendidikan/article/viewFile/516/491

Handayani, L. (2020). Keuntungan , Kendala dan Solusi Pembelajaran Online Selama Pandemi Covid-19: Studi Ekploratif di SMPN 3 Bae Kudus. Journal Industrial Engineering \& Management Research, $1(2), 16$.

Irfanudin, A. M., Kurniawati, E., Jamaluddin, J., \& ... (2020). Strategi Berbisnis Online Ditengah Pandemi Corona Virus Disease 2019 Covid-19. Dedikasi _.., $\quad 1(1), \quad$ 63-68. http://openjournal.unpam.ac.id/index.php/DKP/article/view/6394

Nugraha, M. (2018). Manajemen Kelas Dalam Meningkatkan Proses Pembelajaran. Tarbawi: Jurnal Keilmuan Manajemen Pendidikan, 4(01), 27. https://doi.org/10.32678/tarbawi.v4i01.1769

Patimah, S. (2020). ... Aktivitas Pembelajaran Matematika Pada Materi Pecahan Campuran Berbasis Daring (Melalui Aplikasi Whatsapp) Di Masa Pandemi .... JKPD (Jurnal Kajian Pendidikan Dasar), 5. https://journal.unismuh.ac.id/index.php/jkpd/article/view/3679

Ratnawati, E. (2016). Karakteristik Teori-Teori Belajar Dalam Proses Pendidikan (Perkembangan Psikologis Dan Aplikasi). Edueksos: Jurnal Pendidikan Sosial \& Ekonomi, 4(2), 1-23. 
Saleh, A. R., Sumarni, E., \& Safitri, S. R. (2014). K Ajian a Nalisis K Epuasan P Elanggan. Jurnal Pustakawan Indonesia, 13(2), 15-27.

Taunu, E. S. H., \& Iriani, A. (2019). Evaluasi Program Penguatan Pendidikan Karakter Terintegrasi Mata Pelajaran Matematika di SMP Negeri. Kelola: Jurnal Manajemen Pendidikan, 6(1), 64-73. https://doi.org/10.24246/j.jk.2019.v6.i1.p64-73

Wibowo, T. (2019). Pembelajaran Matematika dan Risetnya di Era Revolusi Industri 4.0. Prosiding Sendika, 5(1), 676-686.

Wulandari, A., Rahman, F., Pujianti, N., Sari, A. R., Laily, N., Anggraini, L., Muddin, F. I., Ridwan, A. M., Anhar, V. Y., Azmiyannoor, M., \& Prasetio, D. B. (2020). Hubungan Karakteristik Individu dengan Pengetahuan tentang Pencegahan Coronavirus Disease 2019 pada Masyarakat di Kalimantan Selatan. Jurnal Kesehatan Masyarakat Indonesia, 15(1), 42. https://doi.org/10.26714/jkmi.15.1.2020.42-46 